\title{
KULTURisk regional risk assessment methodology for water-related natural hazards - Part 2: Application to the Zurich case study
}

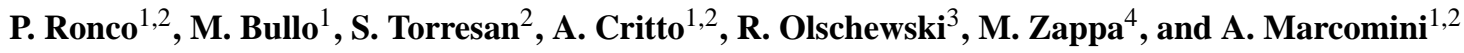 \\ ${ }^{1}$ Dept. of Environmental Sciences, Informatics and Statistics, University Ca' Foscari of Venice, Venice, Italy \\ ${ }^{2}$ Euro-Mediterranean Centre on Climate Change (CMCC), Impacts on Soil and Coast Division, Lecce, Italy \\ ${ }^{3}$ Swiss Federal Research Institute WSL, Economics and Social Sciences, Birmensdorf, Switzerland \\ ${ }^{4}$ Swiss Federal Research Institute WSL, Mountain Hydrology and Mass Movements, Birmensdorf, Switzerland \\ Correspondence to: A. Marcomini (marcom@unive.it)
}

Received: 9 June 2014 - Published in Hydrol. Earth Syst. Sci. Discuss.: 11 July 2014

Revised: 7 January 2015 - Accepted: 2 March 2015 - Published: 27 March 2015

\begin{abstract}
The aim of this paper is the application of the KULTURisk regional risk assessment (KR-RRA) methodology, presented in the companion paper (Part 1, Ronco et al., 2014), to the Sihl River basin, in northern Switzerland. Flood-related risks have been assessed for different receptors lying on the Sihl River valley including Zurich, which represents a typical case of river flooding in an urban area, by calibrating the methodology to the site-specific context and features. Risk maps and statistics have been developed using a 300-year return period scenario for six relevant targets exposed to flood risk: people; economic activities: buildings, infrastructure and agriculture; natural and semi-natural systems; and cultural heritage. Finally, the total risk index map has been produced to visualize the spatial pattern of flood risk within the target area and, therefore, to identify and rank areas and hotspots at risk by means of multi-criteria decision analysis (MCDA) tools. Through a tailored participatory approach, risk maps supplement the consideration of technical experts with the (essential) point of view of relevant stakeholders for the appraisal of the specific scores weighting for the different receptor-relative risks. The total risk maps obtained for the Sihl River case study are associated with the lower classes of risk. In general, higher (relative) risk scores are spatially concentrated in the deeply urbanized city centre and areas that lie just above to river course. Here, predicted injuries and potential fatalities are mainly due to high population density and to the presence of vulnerable people; flooded buildings are mainly classified as continuous and discontinuous urban fabric; flooded roads, pathways and railways, most of them in regards to the Zurich central station (Hauptbahn-
\end{abstract}

hof) are at high risk of inundation, causing severe indirect damage. Moreover, the risk pattern for agriculture, natural and semi-natural systems and cultural heritage is relatively less important mainly because the scattered presence of these assets. Finally, the application of the KR-RRA methodology to the Sihl River case study, as well as to several other sites across Europe (not presented here), has demonstrated its flexibility and the possible adaptation of it to different geographical and socioeconomic contexts, depending on data availability and particulars of the sites, and for other (hazard) scenarios.

\section{Introduction}

Presently, one of the major environmental issues appearing more often at the global scale is the increasing threat of natural disasters. Among the variety of disasters, flooding has significant impacts on human activities as it can threaten people's lives, property, assets, services and the environment. Assets at risk can include housing, transport and public service infrastructure, as well as commercial, industrial and agricultural enterprises. Flooding can lead to severe impacts on local communities, including health, social, economic and environmental aspects (Mazzorana et al., 2012). In this sense, unsustainable development can exacerbate the consequences of flooding by accelerating and increasing surface water runoff, altering watercourses and removing floodplain storage (OPW, 2009). Additionally, the frequency and magnitude of flood events are currently intensifying due to changes 
in temperature, precipitation, glaciers and snow cover, triggered by the dynamics of climate change. Projected changes in precipitation regimes will also contribute to altering the intensity and frequency of rain-fed floods and possibly also of flash floods (IPCC, 2012). In Europe, floods account for the biggest share of damage inflicted by natural disasters, both in economic, environmental and social terms, including the loss of life (see Statistics about natural disasters losses and frequency in Europe for the period 1980-2008. Source: EMDAT, 2009).

Particularly, in Switzerland frequent events alternating with quieter periods have occurred over the last 150 years (Bründl et al., 2009). In northern Switzerland, indeed, numerous floods were recorded between 1874 and 1881 and from 1968 onwards, while few floods occurred in-between. Since the beginning of last century, three massive flood events have occurred (1999, 2005 and 2007, SchmockerFackel and Naef, 2010). Recent research conducted by Hilker et al. (2009) and Badoux et al. (2014) estimated an approximate EUR 8 billion of total monetary loss due to flooding, debris flow, landslides and rockfalls, where $56 \%$ of this damage was caused by six individual flood events from 1978 to 2005 , and $37 \%$ due to sediment transport.

On these bases, the proactive and effective engagement of scientists, stakeholders, policy and decision makers towards the challenging objective of mitigating the impact of floods is dramatically needed. In fact, only over the last few years the science of these events, their impacts, and options for adaptation has become robust enough to support and develop comprehensive and mature assessment strategies (IPCC, 2012). Several methodologies to assess the risk posed by water-related natural hazards have been proposed within the scientific community, but very few of them can be adopted to fully implement the last European Flood Directive (FD). Through a tailored regional risk assessment (RRA) approach, the recently phased out FP7-KULTURisk Project (Knowledge-based approach to develop a cULTUre of Risk prevention - KR) developed a state-of-the-art risk methodology to assess the risk posed by a variety of water-related hazards. The KR-RRA methodology has been thoroughly presented by Ronco et al. (2014) in the companion paper, Part 1. The RRA approach is generally aimed at providing a quantitative and systematic way to estimate and compare the impacts of environmental problems that affect large geographic areas (Hunsaker et al., 1990). By means of different, more or less sophisticated algorithms, these tools target broaderscale (environmental) criticalities, their contribution and influence at local scale as well as the cumulative effects of local-scale issues on regional receptors to support the development of knowledge-based mitigation measures. Accordingly, RRA becomes important when policymakers are called to face problems caused by a multiplicity of hazards, widely spread over a large area, which impact a multiplicity of endpoints of regional interest. The proposed KR-RRA methodology follows the theoretical approach proposed by Landis

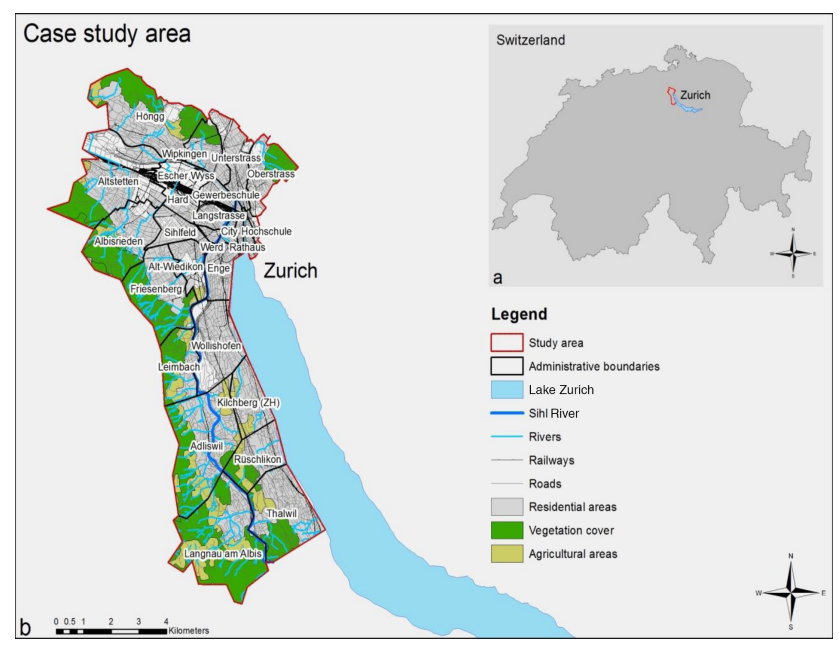

Figure 1. The case study area: (a) its location in Switzerland and (b) its main characteristics.

and Weigers (1997) and it has been used in a wide range of cases (Pasini et al., 2012; Torresan et al., 2012), through the implementation of the following actions: (i) identification of the different sources, habitats and impacts; (ii) ranking the (relative) importance of the different components of the risk assessment; (iii) spatial visualization of the different components of the risk assessment; (iv) relative risk estimation.

Finally, through the integration of hazard, exposure and vulnerability, considered by UNISDR (2005) and IPCC (2012) as (main) pillars of the risk concept, the proposed KR-RRA methodology represents a benchmark for the implementation of the Floods Directive at the European level. This innovative, effective and integrated approach has been used for assessing the risk of flood posed by the Sihl River to the city of Zurich and surroundings, by considering different flood impacts on multiple receptors (i.e. people, economic activities, natural and semi-natural systems, cultural heritage) at the mesoscale level.

\section{The Sihl River valley}

The Sihl is a $68 \mathrm{~km}$ long alpine river located in the foothills of the Swiss Alps. The river sources (basin coverage: $336 \mathrm{~km}^{2}$ ) are located at Drusberg in the canton of Schwyz (SZ), in central Switzerland. Downstream, it flows through the artificial Lake Sihl regulated by a concrete dam (upstream basin: $156 \mathrm{~km}^{2}$ ) entering the canton of Zurich (ZH) through the Sihl River valley and flowing parallel with Lake Zurich, separated by a sequence of hills. Finally, the Sihl joins the Limmat River at Platzspitz in the Zurich city centre (downstream basin: $180 \mathrm{~km}^{2}$ ). Similar to many alpine rivers, the Sihl preserves most of its natural morphological pattern of a meandering river and it is not navigable. 
The Sihl River valley is extensively wooded and, specifically, the forest on the higher valley is classified as coniferous and mixed forest. Since the year 2000, the Sihl forest has been declared a (protected) natural reserve, and several areas along the river have become attractive for recreational purposes and are important ecological habitats. The river valley is also cultivated with crops and pastures. The upstream part of the river consists of several small torrential rivers, characterized by the intense transport of sediments (Rickenmann et al., 2012) and driftwood (Turowski et al., 2013). The intense transport of sediment is particularly evident when the brown waters of the Sihl (Fig. 2) join the clear waters of the Limmat River, while driftwood accumulation under major bridges and, most importantly, below Zurich central station represents a serious threat along the entire river channel.

As far as the administrative characterization is concerned, the Sihl River valley includes parts of the districts of Einsiedeln (SZ) (upper Sihl valley), Horgen ( $\mathrm{ZH})$ and Zurich (lower Sihl valley). The studied area $\left(77.97 \mathrm{~km}^{2}\right)$ covers only the lower part of the valley and in particular the city of Zurich with its 21 districts (Albisrieden, Alt-Wiedikon, Altstetten, City, Enge, Escher Wyss, Friesenberg, Gewerbeschule, Hard, Hochschule, Höngg, Langstrasse, Leimbach, Lindenhof, Oberstrass, Rathaus, Sihlfeld, Unterstrass, Werd, Wipkingen, Wollishofen) and 5 municipalities (Adliswil, Kilchberg, Langnau am Albis, Rüschlikon and Thalwil) (see Fig. 1).

The area of study is densely populated, in particular in its lower part close to the city of Zurich, which is located north and north-west of the homonymous lake. According to Coordination of Information on the Environment (CORINE) Land Cover (CLC) classifications (EEA, 2007), residential area covers $41.28 \mathrm{~km}^{2}$ (more than half of the case study area) and the total population is 289029 (Statistical Office of the Canton of Zurich, 2011; www.statistik.zh.ch), while $20.19 \mathrm{~km}^{2}$ is covered by forest and only $7.67 \mathrm{~km}^{2}$ is devoted to agriculture. Several cultural heritage hotspots are present in the valley and especially in the Zurich city centre: the Swiss National Museum, the Kaspar Escher House, the Fraumünster and the Bühl church, among others.

\section{Hydrological pattern and regime}

The Sihl River basin is particularly prone to flash floods: during wintertime snow accumulates in the headwater regions and snowmelt governs runoff generation in late spring and early summer. Flash floods triggered by intense thunderstorms may be responsible for high amounts of damage in the upstream areas (e.g. the region of Einsiedeln), but rarely lead to critical peak-runoff in the downstream part of the basin. Critical runoff for the environs of Zurich is normally caused by long-lasting rainfall events that lead to the overspill of Lake Sihl (Scherrer, 2013) This process is generally slow, but severe floods can occur whenever the rate of water input

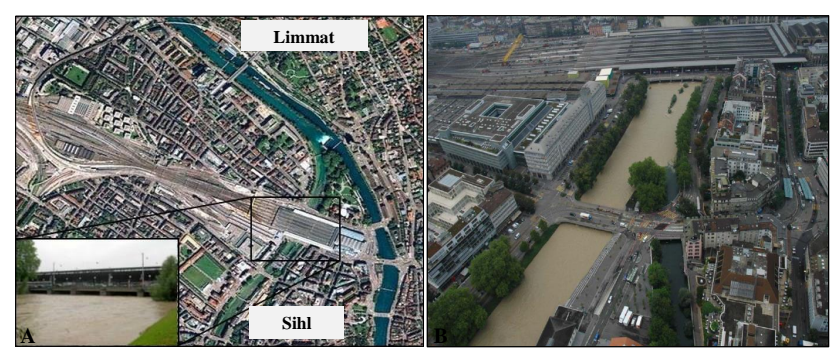

Figure 2. Sihl River flowing beneath Zurich main train station before the confluence with the Limmat River: (a) from Google Maps; in the inset, the situation in August 2005 during a flood event, source: A. Senn (WSL). (b) Sihl River flowing underneath the Zurich main train station in August 2005 (discharge: $280 \mathrm{~m}^{3} \mathrm{~s}^{-1}$ ), source: Office of Waste, Water, Energy and Air, Zürich (M. Oplatka).

exceeds the ability of the soil to absorb it or when the amount of water exceeds the natural storage capacities of soil, rivers, lakes and reservoirs. In fact, Sihl River represents the largest flood threat for the Zurich, Switzerland's most populous city (Addor et al., 2011): just before joining the Limmat River, the Sihl flows beneath the central station of Zurich (Zürich Hauptbahnhof HB) located in the city centre, as showed in Fig. 2.

Pro Sihltal (2008) reported the most important floods that have occurred along the Sihl River valley during the last 3 centuries. In 1910, in particular, a massive event flooded Zurich central station with more than $40 \mathrm{~cm}$ of water, and some railway tracks were badly damaged and the service was interrupted; Leimbach and Adliswil districts were under $1 \mathrm{~m}$ of water and some buildings of the Swiss National Museum at Platzspitz were completely flooded. In 1937, the artificial multipurpose Lake Sihl was created both for hydropower and as retention basin, to reduce the frequency of downstream flooding (Schwanbeck et al., 2010). Until 1999, no more floods had been registered in the area but in 2005 and 2007 severe inundations demonstrated that the buffer capacity of Lake Sihl as retention basin is not enough to mitigate the impact of extreme flood events during heavy rainfall seasons. In fact, even if the discharge of the Sihl is relatively modest and most of the water from the upstream catchment are usually diverged into Lake Zurich, in the case of heavy precipitation, dam overflow might occur and, according to the emergency regulation procedures, discharges as high as $470 \mathrm{~m}^{3} \mathrm{~s}^{-1}$ can be released into the Sihl River, with dramatic consequences downstream (Addor, 2011).

The extreme rainfall of August 2005, extensively described in Bezzola and Hegg (2007) and Jaun et al. (2008), triggered a (preliminary) flood risk assessment for the entire catchment (Schwanbeck et al., 2007) and, finally, the planning of few immediate, intermediate and long-term prevention measures. However, out of the planned ones, only the early warning system (EWS) to forecast extreme events and 
Table 1. Data set used for the application of the KULTURisk RRA methodology within the Sihl River valley.

\begin{tabular}{|c|c|c|c|c|c|c|c|}
\hline \multicolumn{2}{|c|}{ Step of assessment } & \multirow[t]{2}{*}{ People } & \multirow[t]{2}{*}{ Buildings } & \multirow{2}{*}{\multicolumn{2}{|c|}{$\begin{array}{l}\text { Infrastructure Agriculture } \\
\text { ater depth, velocity, flood coverage } \\
\text { GIS WSL, 2006, 1:100000) for debris fact }\end{array}$}} & \multirow{2}{*}{$\begin{array}{l}\text { Natural and semi- } \\
\text { natural systems }\end{array}$} & \multirow[t]{2}{*}{ Cultural heritage } \\
\hline Hazard & Data set & & & & & & \\
\hline & $\begin{array}{l}\text { Work load } \\
\text { (man-days) }\end{array}$ & 3 & 1 & 1 & 1 & 1 & 0.5 \\
\hline \multirow[t]{2}{*}{ Exposure } & Data set & $\begin{array}{l}\text { - People in } \\
\text { residential areas } \\
\left({ }^{2}, 2011\right) \\
\text { - Switzerland } \\
\text { CORINE Land } \\
\text { Cover map } \\
\left({ }^{3}, \text { GIS WSL, }\right. \\
2006,1: 100000)\end{array}$ & $\begin{array}{l}\text { - Building } \\
\text { footprint map } \\
\left({ }^{1} \text { TLM3D, 2013, }\right. \\
1: 5000) \\
\text { - Switzerland } \\
\text { CORINE Land } \\
\text { Cover map } \\
\left({ }^{3}, \text { GIS WSL, }\right. \\
2006,1: 100000)\end{array}$ & $\begin{array}{l}\text { - Roads } \\
\text { (Strasse_CH_line) } \\
\text { and Railways } \\
\text { (Eisenbahn_CH_line) } \\
\text { maps ( }{ }^{1} \text { TLM3D, } \\
\text { 2012, } 1: 5000) \\
\text { - Switzerland } \\
\text { CORINE Land } \\
\text { Cover map } \\
\left({ }^{3}, \text { GIS WSL, }\right. \\
\text { 2006, } 1: 100000)\end{array}$ & $\begin{array}{l}\text { - Switzerland } \\
\text { CORINE Land } \\
\text { Cover map } \\
\left({ }^{3}, \text { GIS WSL, }\right. \\
2006,1: 100000)\end{array}$ & $\begin{array}{l}\text { - Switzerland } \\
\text { CORINE Land } \\
\text { Cover map } \\
\left({ }^{3}, \text { GIS WSL, }\right. \\
2006,1: 100000)\end{array}$ & $\begin{array}{l}\text { - Protected } \\
\text { objects of } \\
\text { historical } \\
\text { interest map } \\
\text { (Denkmalschutz- } \\
\text { objekte, }{ }^{1}, 2013 \text {, } \\
1: 5000)\end{array}$ \\
\hline & $\begin{array}{l}\text { Work load } \\
\text { (man-days) }\end{array}$ & 3 & 2 & 2 & 2 & 2 & 1 \\
\hline \multirow[t]{2}{*}{ Vulnerability } & Data set & $\begin{array}{l}\text { - Percentage of } \\
\text { disabled in Zurich } \\
\text { city and data } \\
\text { census } \\
(5,2010)\end{array}$ & - & - & $\begin{array}{l}\text { - Digital map of } \\
\text { soil coverage of } \\
\text { Switzerland }\left({ }^{4} \text {, }\right. \\
2012,1: 200000)\end{array}$ & $\begin{array}{l}-25 \text { m DEM }\left(^{3} \text {, }\right. \\
\text { GIS WSL, 1994) } \\
\text { - Digital map of } \\
\text { soil coverage of } \\
\text { Switzerland }\left({ }^{4}\right. \\
2012,1: 200000)\end{array}$ & - \\
\hline & $\begin{array}{l}\text { Work load } \\
\text { (man-days) }\end{array}$ & 1 & - & - & 1 & 2 & - \\
\hline Risk & $\begin{array}{l}\text { Work load } \\
\text { (man-days) }\end{array}$ & 0.5 & 0.5 & 0.5 & 0.5 & 0.5 & 0.5 \\
\hline
\end{tabular}

${ }^{1}$ GIS Centre of the Canton of Zurich; ${ }^{2}$ Statistical Office of the Canton of Zurich; ${ }^{3}$ Swiss Federal Office of Topography; ${ }^{4}$ Swiss Federal Office for Agriculture; ${ }^{5}$ Swiss Federal Statistical Office.

mitigate their impact has been implemented so far, while intermediate and long-term prevention measures, such as the overflow channel, are still under analysis and discussion by the different stakeholders and local institutions/authorities (Zappa et al., 2015). The complexity of hydrological pattern of the Sihl River valley and the need for a planned strategy of prevention measures demands a broader integrated approach, in order to assess the flood risk to multiple receptors, and a suite of effective tools to identify and prioritize areas and targets at risk in order to finally evaluate the benefits of different prevention scenarios (e.g. Buchecker et al., 2013).

\section{Data set characterization and processing}

The data set required for the application of the KR-RRA methodology includes (i) characterization of the intensity and the frequency of the flood events in the framework of a specific hazard scenario (e.g. hazard metrics such as flow velocity, water depth, flood extension, return period); (ii) spatial pattern of the considered receptors (e.g. people, economic activities, natural and semi-natural systems, cultural heritage) in order to perform the exposure assessment; (iii) relevant indicators (e.g. percentage of disabled people, slope, soil type) for characterizing the degree to which the different receptors could be affected by the (flood) hazard (i.e. the vulnerabil- ity assessment). The data set has been mainly provided by the GIS Centre of the Canton of Zurich, the Swiss Federal Office of Topography, the Statistical Office of the Canton of Zurich, the Swiss Federal Statistical Office (BFS, Bundesamt für Statistik) and the Swiss Federal Office for Agriculture (FOAG), (Bundesamt für Landwirtschaft, BLW) in raster, vector graphic or numerical format, as specified in Table 1 .

For the risk assessment to agriculture and natural and semi-natural systems, the CLC data set (EEA, 2007, with spatial resolution of $1: 100000$ ) has been used to characterize the targets at the spatial level at regional scale; for buildings, infrastructure and cultural heritage, data with a finer resolution (spatial resolution of $1: 5000$ ) has been used. Finally, to characterize the people affected, residential census data provided has been used to compute the number of residents within cells of $25 \mathrm{~m}^{2}$ size. The work load (in terms of man-days) required to process the data set and produce the maps of the four assessment steps is also presented in Table 1 .

\subsection{Hazard data processing}

As explained by Ronco et al. (2014) in the companion paper (Part 1), the hazard assessment is aimed at identifying the relevant physical metrics (water depth, velocity and flood 
Table 2. Flood metrics to assess hazard for different receptors.

\begin{tabular}{lll}
\hline Hazard assessment & Selected flood metric & Receptor \\
\hline \multirow{3}{*}{ Flood hazard } & Water depth $(\mathrm{m})$ & People, buildings \\
\cline { 2 - 3 } & Flow velocity $\left(\mathrm{m} \mathrm{s}^{-1}\right)$ & People, buildings, agriculture \\
\cline { 2 - 3 } & Flood extension $\left(\mathrm{km}^{2}\right)$ & $\begin{array}{l}\text { Infrastructure, natural and semi-natural systems, } \\
\text { cultural heritage }\end{array}$ \\
\cline { 2 - 3 } & Debris factor & People \\
\hline
\end{tabular}

Table 3. Debris factor (DF) for different pattern of water depth and velocity in urban areas (DEFRA, 2006).

\begin{tabular}{lc}
\hline $\begin{array}{l}\text { Flood depth }(d) \\
\text { and velocity }(v)\end{array}$ & $\begin{array}{c}\text { Debris factor (DF) } \\
\text { for urban areas }\end{array}$ \\
\hline$d \leq 0.25 \mathrm{~m}$ & 0 \\
$0.25 \mathrm{~m}<d<0.75 \mathrm{~m}$ & 1 \\
$d \geq 0.75$ or $v>2 \mathrm{~m} \mathrm{~s}^{-1}$ & 1 \\
\hline
\end{tabular}

extension) obtained from hydrodynamics models for the different scenarios to be investigated (baseline or alternative). The methodology makes different use of the various hazard metrics depending on the analysed receptors in order to assess the relative risk, as depicted in Table 2.

Maps of flooded area, including patterns of water depth and velocity can be computed by commercial, more or less sophisticated, hydraulics models. Moreover, the debris factor, which ranges between 0 and 1 to account for, respectively, the low and high probability that debris would lead to a significant hazard, can be easily assigned according to different ranges of water depth and velocity, as per Table 3 .

However, while existing flood hazard maps can be easily used to estimate flood depth, they only rarely provide information on flow velocity (DEFRA, 2006). This is the case for the Sihl River valley, where patterns of velocity were not available. Here, only data about water depth and intensity (namely the combination between water depth and velocity) classified in range of values (classes) were provided by local authorities, without any explicit specification regarding the particular (hydraulic) models that were used (see Tables 4 and 5).

The pattern of water velocities was calculated as follows. Based on a particular precautionary principle (highest depth $d$ and velocity $v$ are associated with highest hazard level), the highest values for depth $d$ and the $v \cdot d$ product were selected for each class (e.g. $d=0.5 \mathrm{~m}$ for the class 2 of Table 4 , and $v \cdot d=0.5 \mathrm{~m}^{2} \mathrm{~s}^{-1}$ for class 1 of Table 5). Moreover, due to the specific range of values referred to in the case study, classes 2 and 3 of intensity and classes 6 and 7 of depth have been merged. Now, provided that the $v \cdot d$ product and $d$ are known
Table 4. Classification of water depth from flood hazard maps provided by the GIS Centre of the Canton of Zurich.

\begin{tabular}{cr}
\hline Depth class & $(\mathrm{m})$ \\
\hline 1 & $<0.25$ \\
2 & $0.25-0.50$ \\
3 & $0.50-0.75$ \\
4 & $0.75-1.00$ \\
5 & $1.00-1.50$ \\
6 & $1.50-2.00$ \\
7 & $>2.00$ \\
\hline
\end{tabular}

Table 5. Classification of intensity parameter (function of water depth $-d$, and velocity $-v$ ) from flood hazard maps provided by the GIS Centre of the Canton of Zurich.

\begin{tabular}{|c|c|c|}
\hline $\begin{array}{c}\text { Intensity } \\
\text { class }\end{array}$ & Description & Conditions \\
\hline 1 & Low & $\begin{aligned} d & <0.5 \mathrm{~m} \text { or } \\
v \cdot d & <0.5 \mathrm{~m}^{2} \mathrm{~s}^{-1}\end{aligned}$ \\
\hline 2 & Medium & $\begin{array}{c}0.5<d<2.0 \mathrm{~m} \text { or } \\
0.5 \mathrm{~m}^{2} \mathrm{~s}^{-1}<v \cdot d<2.0 \mathrm{~m}^{2} \mathrm{~s}^{-1}\end{array}$ \\
\hline 3 & High & $\begin{aligned} d & >2 \mathrm{~m} \text { or } \\
v \cdot d & >2 \mathrm{~m}^{2} \mathrm{~s}^{-1}\end{aligned}$ \\
\hline
\end{tabular}

individual values, and not a range of values as it was before, it was easy to derive the pattern of velocities (see Table 6).

\section{Baseline and alternative hazard scenarios}

The KULTURisk methodological framework requires the preliminary setting and analysis of different flood scenarios (baseline and alternative) where structural and/or nonstructural solutions to mitigate the risk are planned.

As request by the European Flood Directive (2007/60/EC), the baseline scenarios should be based on deterministic flood hazard maps, where flood-prone areas are classified according to different classes of frequency of the event (high, medium and low), based on the concept of return period (TR) of the hazardous event, as follows: 
Table 6. Computation of (individual) values of velocity $(v)$ from available data (water depth $-d$, debris factor $-\mathrm{DF}$, and intensity $-I$ ).

\begin{tabular}{ccccc}
\hline & & \multicolumn{2}{c}{ Velocity $v=I / d$} \\
\cline { 3 - 4 } $\begin{array}{c}\text { Depth } \\
\text { classes }\end{array}$ & $\begin{array}{c}\text { Depth of } \\
\text { reference }(d)(\mathrm{m})\end{array}$ & $\mathrm{DF}$ & $\begin{array}{c}\text { Intensity class 1 } \\
(d \cdot v=0.5)\left(\mathrm{m} \mathrm{s}^{-1}\right)\end{array}$ & $\begin{array}{c}\text { Intensity classes 2 and 3 } \\
(d \cdot v=2)\left(\mathrm{m} \mathrm{s}^{-1}\right)\end{array}$ \\
\hline 1 & 0.25 & 0 & 2.00 & 8.00 \\
2 & 0.5 & 1 & 1.00 & 4.00 \\
3 & 0.75 & 1 & 0.67 & 2.67 \\
4 & 1 & 1 & 0.50 & 2.00 \\
5 & 1.5 & 1 & 0.33 & 1.33 \\
6 and 7 & 2 & 1 & 0.25 & 1.00 \\
\hline
\end{tabular}

- Frequent event TR $<30$ years - high probability of floods

- Average event 30 years $<\mathrm{TR}<100$ years - medium probability of floods

- Rare event 100 years $<\mathrm{TR}<300$ years - low probability of floods.

Spatially distributed flood hazard maps are normally used by property owners, local authorities and land planners to characterize the hazard over relatively large area, to prepare for floods and to properly manage the events (EEA, 2009). As far as this study is concerned, the available flood hazard maps of the three classes of hazards (30-, 100- and 300-year return periods) have been provided by the GIS Centre of the Canton of Zurich. The low-probability-high-intensity 300-year return period scenario has been considered the most relevant for the purpose of this study (see Fig. 3) since the other two scenarios (30 and 100 years) only marginally affect the typically prone area of the Sihl valley and, in particular, do not affect the central station of Zurich. In fact, according to local stakeholders, experts and forensic analysis of past flood events, this asset has been considered the hottest spot of analysis. Moreover, relative risk maps for the first two (marginal) hazard scenarios have not been presented as they are not relevant to the overall objective of the study, which is to test the degree of applicability of an innovative methodological approach in an (example) case study. The aim is to support the (case-specific) decision-making process, not to assess the complete suite of risk patterns according to the different (and unlimited) plausible scenarios that could characterize the hazard for a particular case study. Finally, by assessing the most catastrophic configuration, the selected (baseline) scenario provides the opportunity to plan mitigation, adaptive, response and preparedness actions in a (very) precautionary framework.

In 2008, an early warning system (EWS IFKIS Hydro Sihl) has been installed along the Sihl River valley (Romang et al., 2011; Bruen et al., 2010). The EWS IFKIS is a hydro-meteorological ensemble prediction system based on atmospheric forecasts provided by the (deterministic) model

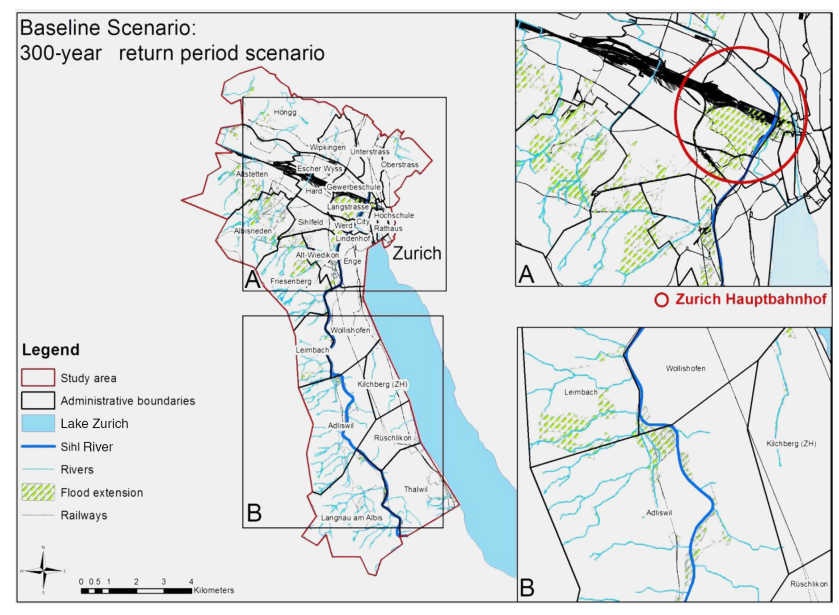

Figure 3. Baseline scenario for Sihl case study of a 300-year return period flood scenario; inset A shows the Zurich central station, inset $\mathrm{B}$ the upstream river valley area.

COSMO-7 and the (probabilistic) model COSMO-LEPS. Coupled with the improvement of the flood retention system expected by extending the reservoir buffering capacity of Lake Sihl, the EWS contributes to a consistent reduction of flood risk magnitude along the Sihl River valley. However, in this study the baseline scenario considers the situation before the establishment of this mitigation measure since the reduction of the flood risk for the EWS cannot be assessed to a reliable degree because data on larger flood events are not yet available (Addor et al., 2011).

The Canton of Zurich is currently discussing further prevention measures such as the overflow channel (close to Langnau am Albis, Fig. 1) diverging flood peaks along the Sihl valley into Lake Zurich, or the larger connection between Lake Sihl and Lake Zurich to both allow for increased hydropower production and accelerated drawdown of the lake to increase the buffering capacity of Lake Sihl during critical flood events. Furthermore, the development of a reservoir for driftwood is being considered in Langnau am Albis (Fig. 1). If established, these prevention measures could significantly reduce the flood risk of the Sihl to a 
lower level but details on the expected impact under different prevention measures are still under analysis and discussion (Zappa et al., 2015). Due to this, alternative scenarios have not been considered in this study.

\section{Results of the KR-RRA application to the selected receptors}

The KR-RRA methodology presented in the companion paper (Part 1) has been applied to the Zurich case study by considering the whole suite of receptors at risk: people; economic activities (buildings, infrastructure and agriculture); natural and semi-natural systems; and cultural heritage. Through the sub-sequential implementation of the hazard, exposure, susceptibility and risk assessments, GIS-based maps and related statistics of total and receptor-related risks have been produced and are presented in this section.

\subsection{Risk to people}

\subsubsection{Assessment}

According to the KR-RRA procedure (see Part 1, Eq. 1) and following the data processing presented above, the hazard scores for Sihl River case study have been calculated and reported in Table 7. Scores range from 0.9 to 6 , where increasing values mean an increasing hazard for people.

As far as the exposure assessment is concerned, the total population living in residential areas is of 289 029. The largest district is Altstetten $\left(7.48 \mathrm{~km}^{2}\right.$ with 30148 habitants), while Sihlfeld and Gewerbeschule are the most densely populated ones (11759 habitants $\mathrm{km}^{-2}$ and 13163 habitants $\mathrm{km}^{-2}$ respectively). Most of the upper part of the Sihl valley has a lower density, between 826 and 5981 habitants $\mathrm{km}^{-2}$. These data have been spread over $25 \mathrm{~m}$ resolution cells for residential area of each district. Moreover, the characterization of susceptibility patterns was performed based on the demographic data provided by the Statistical Office of the Canton of Zurich. In particular, it has been assumed that the rate of people with disabilities (5\% over the total population) is spatially homogenous, while the differences among the Suscetibility Factor (SF) score actually depend only on the percentage of elderly residents that ranges from 7.6 to $32.3 \%$. The normalization phase has been performed according the KR-RRA procedure, so the number of injured/killed people has been divided by the number of people living in the district with highest population.

\subsubsection{Results}

The human risk maps (Figs. 4 and 5, Tables 8 and 9) provide the number of injuries $\left(R_{1}\right)$ and fatalities $\left(R_{2}\right)$ spatially distributed along the Sihl River valley. As for the other receptors, the classification is obtained through equal-interval methods. The predicted number of total injuries is estimated

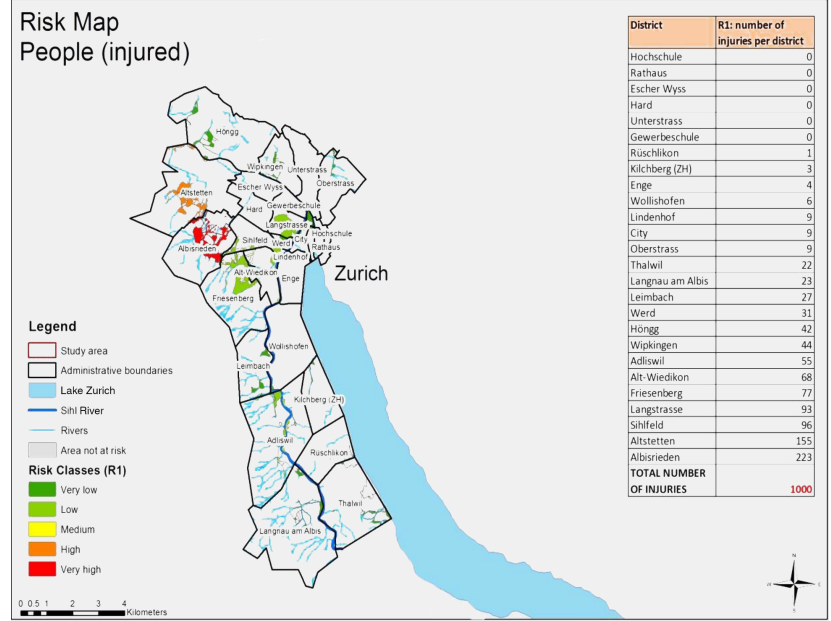

Figure 4. Relative risk map for injured people with statistics at the district level.

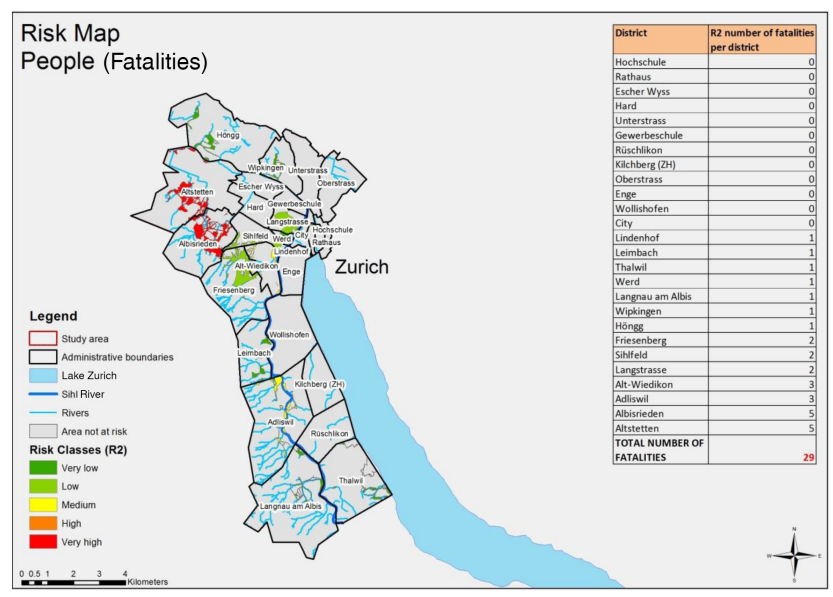

Figure 5. Relative risk map for fatalities with statistics at the district level.

to be 1000 , while the number of total (potential) fatalities is estimated to be 29. Among the affected areas, Albisrieden and Altstetten districts, which are densely populated with medium scores for susceptibility, are expected to suffer several casualties with 223 injuries and 5 fatalities and 155 injuries and 5 fatalities, respectively. It is worth noting that these two districts are normally flooded by the Limmat River, a tributary of the Sihl. Considering the Sihl flood-prone area only, the districts that suffer from the higher numbers of casualties are Adliswil, Alt-Wiedikon, Langstrasse and Sihlfeld, with a range of injuries from 55 to 96 , and 2 to 3 fatalities. The percentage of injured is $0.35 \%$ of the total population of the study area and the percentage killed is $0.01 \%$. These rates suggest that risk to people is generally low, though not negligible, if we consider the high density of the population that is sometimes located within the residential area. 
Table 7. Hazard scores for people computed from available data (water depth $-d$, velocity $-v$, debris factor $-\mathrm{DF}$, and intensity $-I$ ).

\begin{tabular}{lrrrr}
\hline & & \multicolumn{3}{c}{$\mathrm{H}_{\text {people }}=d \cdot v+d \cdot 1.5+\mathrm{DF}$} \\
\hline $\begin{array}{l}\text { Depth } \\
\text { classes }\end{array}$ & $\begin{array}{r}\text { Depth of } \\
\text { reference }(d)(\mathrm{m})\end{array}$ & DF & $\begin{array}{r}\text { Intensity }(I) \text { class 1 } \\
(d \cdot v=0.5)\end{array}$ & $\begin{array}{r}\text { Intensity }(I) \text { classes } \\
2 \text { and 3 }(d \cdot v=2)\end{array}$ \\
\hline 1 & 0.25 & 0 & 0.875 & 2.375 \\
2 & 0.5 & 1 & 2.25 & 3.75 \\
3 & 0.75 & 1 & 2.625 & 4.125 \\
4 & 1 & 1 & 3 & 4.5 \\
5 & 1.5 & 1 & 3.75 & 5.25 \\
6 and 7 & 2 & 1 & 4.5 & 6 \\
\hline
\end{tabular}

Table 8. Relative risk classes and range of values for injuries.

\begin{tabular}{lr}
\hline Risk classes $\left(R_{1}\right)$ & Number of injuries \\
\hline Very low & $1-50$ \\
Low & $50-100$ \\
Medium & $100-150$ \\
High & $150-200$ \\
Very high & $>200$ \\
\hline
\end{tabular}

Table 9. Relative risk classes and range of values for fatalities.

\begin{tabular}{lr}
\hline Risk classes $\left(R_{2}\right)$ & Number of fatalities \\
\hline Very low & 1 \\
Low & 2 \\
Medium & 3 \\
High & 4 \\
Very high & $>5$ \\
\hline
\end{tabular}

As already mentioned, the KR-RRA methodology considers people living in residential areas only, and does not include people occasionally present in commercial, industrial and agricultural areas. Moreover, the methodology does not distinguish between daytime and nighttime. During the daytime, in fact, people are usually located in their workplaces and/or in restaurants, bars, shopping centres, transport facilities (such as the central station of Zurich) and along the streets. Therefore the methodology somewhat underestimates the number of injuries and fatalities in these areas while overestimating injuries and fatalities in residential areas. Finally, it is worth noting that the RRA methodology only partially considers people's coping (and adaptive) capacities since these aspects are fully enclosed in the socioeconomic clusters (SERRA) of the (complete) KR methodology (see Giupponi et al., 2014).

\subsection{Risk to economic activities: buildings}

\subsubsection{Assessment}

Floods have a potential massive impact on buildings infrastructure (e.g. partial or total damage to the structures, damage to the indoor goods), particularly in densely populated area as most of the Sihl River valley. The analysis makes considerable use of the building footprint GIS shapefile (GIS Centre of the Canton of Zurich TLM3D building footprint) for the spatial localization of the buildings at risk (total number of buildings: 19430; total surface covered by buildings: $10.67 \mathrm{~km}^{2}$ ). Moreover, when coupling these data with the hazard maps, it is possible to distinguish between flooded buildings of different use categories (i.e. residential, commercial and industrial areas). Table 10 shows the statistics regarding the presence and coverage of buildings which could potentially be flooded, according to the different CLC classes.

As already reported by the companion paper (Part 1), the vulnerability assessment assumes that, at the mesoscale level, the buildings are characterized by the same structure and, therefore, by the same susceptibility score. Finally, the risk assessment to buildings estimates the number, surface and percentage of flooded buildings of different uses; the related normalization phase for buildings has been developed by considering normalized scores where values from 0 (no risk) to 1 (maximum risk) are assigned according to the different classes of risk.

\subsubsection{Results}

The GIS-based risk map (Fig. 6) highlights the spatial distribution of the risk to buildings across the studied area. As the intensity of the considered scenario is lower than the fixed threshold, all of the affected buildings are only flooded and do not suffer from dramatic structural damage. However, the flooding can still have dramatic consequences for infrastructure because many assets of primary importance, such as heating and electricity and water services, are normally located below ground level. The total number of buildings at risk is 3267 and the related surface area is $2.2 \mathrm{~km}^{2}$ (Table 11). 
Table 10. Statistics about the buildings coverage along the Sihl River valley.

\begin{tabular}{lrrrr}
\hline Buildings: CLC class & Total no. & $\%$ & coverage $\left(\mathrm{km}^{2}\right)$ & $\%$ of coverage \\
\hline 111-112: continuous urban fabric - discontinuous urban fabric & 18255 & 94.0 & 8.9 & 83.4 \\
121: industrial or commercial units & 780 & 4.0 & 1.4 & 12.9 \\
122: road and rail networks and associated land & 100 & 0.5 & 0.3 & 3.1 \\
141-142: green urban areas - sport leisure facilities & 295 & 1.5 & 0.1 & 0.6 \\
\hline Total & 19430 & 100.0 & 10.7 & 100.0 \\
\hline
\end{tabular}

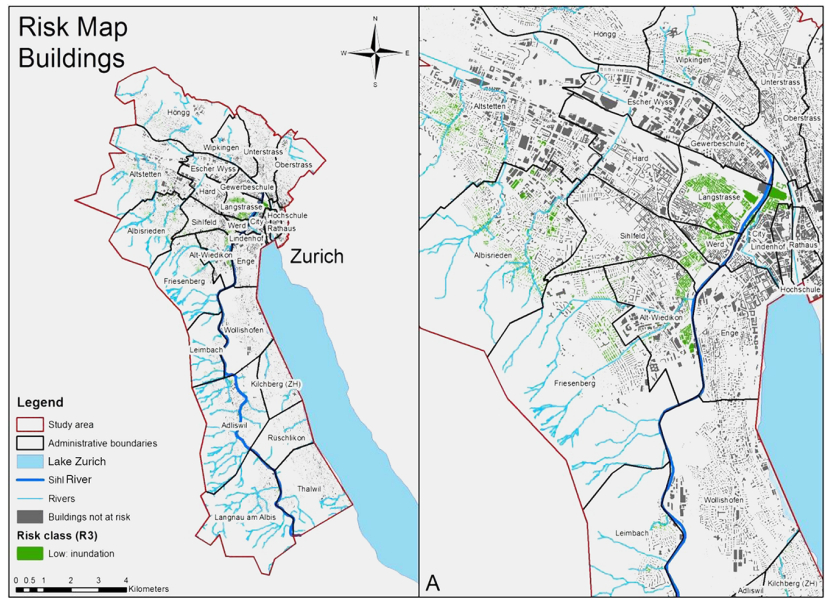

Figure 6. Relative risk map of buildings (left) and the city centre (right).

Table 11. Relative risk classes and range of values for buildings.

\begin{tabular}{llr}
\hline Risk classes (R3) & Description & $\begin{array}{r}\text { No. of inundated } \\
\text { buildings }\end{array}$ \\
\hline Not at risk & Not inundated & 16163 \\
Low & Inundation & 3267 \\
Medium & Partial damage & 0 \\
High & Total destruction & 0 \\
\hline
\end{tabular}

The percentage of flooded buildings is around $17 \%$ while the percentage of flooded areas is almost $20 \%$ over the total surface actually covered by buildings.

As already mentioned, the studied area is mostly classified as residential and almost $95 \%$ of flooded buildings belongs to class 1.1.1 and 1.1.2 of CLC (continuous and discontinuous urban fabric) while just less than $6 \%$ of inundated buildings belongs to classes 1.2.1, 1.2.2, 1.4 .1 and 1.4.2 (industrial or commercial units, road and rail networks and associated land, green urban areas and sport leisure facilities). In particular, only 17 objects are classified as infrastructure related to the supply of services (road, rail networks and associated land classes) so the risk for this category is very relevant (most of them are linked to the strategic transportation network of the central station of Zurich). Inset A of Fig. 6 fo- cuses on the districts with higher number of inundated buildings around the Zurich city centre. Several small residential areas would be flooded also in the southern part of the city, namely Leimbach, Adliswil, Thalwil and Langnau am Albis. Table 12 presents the relevant data for the analysed receptor, considering the different use of buildings.

\subsection{Risk to economic activities: infrastructure}

\subsubsection{Assessment}

The strategic network of infrastructure have been identified using the Roads and Railways shapefiles, provided by the GIS Centre of the Canton of Zurich. The information includes the characterization of roads, pathways and railway lines within the study area. Zurich central station represents an important and strategic hub for the cantonal railway network system as well as for the Swiss and European railways network systems: more than 1900 trains pass by the Hauptbahnhof station daily. In fact, urban commuter rail networks are focused in the country's major cities: Zurich, Geneva, Basel, Bern, Lausanne and Neuchatel. Strategic highways and roads also run in and out of Zurich.

The assessment of flood hazards to infrastructure considers the flood extension as relevant flood metric; no other flood metrics (e.g. flow velocity) have been considered because the analysis is not oriented to the evaluation of direct structural damage for infrastructure, but rather to the characterization of the loss of service. The exposure assessment focuses on the spatial localization and distribution of the roads, railways and pathways. All these objects could be geometrically characterized by their linear extension (length) and by their coverage (area). In particular, pathway routes have been considered relevant since many of them are normally used by pedestrian to connect rural area to the city centre, running along the flood prone area of the Sihl River.

\subsubsection{Results}

The infrastructure risk map (Fig. 7 and Table 13) identifies the assets potentially affected by a flood event of 300-year return period. The total extent of road, railways and pathways at risk is around $209 \mathrm{~km}$ out of $1540 \mathrm{~km}$ that are currently located in the study area (less than $14 \%$ of objects are at 
Table 12. Statistics on the risk for buildings for different CLC classes.

\begin{tabular}{lrrrr}
\hline $\begin{array}{l}\text { Risk for buildings } \\
\text { (CLC classes) }\end{array}$ & $\begin{array}{r}\text { Flooded } \\
\text { No. }\end{array}$ & $\begin{array}{r}\text { Flooded } \\
(\%)\end{array}$ & $\begin{array}{r}\text { Flooded } \\
\text { area }\left(\mathrm{km}^{2}\right)\end{array}$ & $\begin{array}{r}\text { Flooded } \\
\text { area } \%\end{array}$ \\
\hline 1.1.1-1.1.2: continuous urban fabric - discontinuous urban fabric & 3075 & 94.1 & 1.8 & 83.4 \\
1.2.1: industrial or commercial units & 154 & 4.7 & 0.3 & 12.4 \\
1.2.2: road and rail networks and associated land & 17 & 0.5 & 0.1 & 4.1 \\
1.4.1-1.4.2: green urban areas - sport leisure facilities & 21 & 0.6 & 0.004 & 0.2 \\
\hline Total & 3267 & 100.0 & 2.2 & 100.0 \\
\hline
\end{tabular}

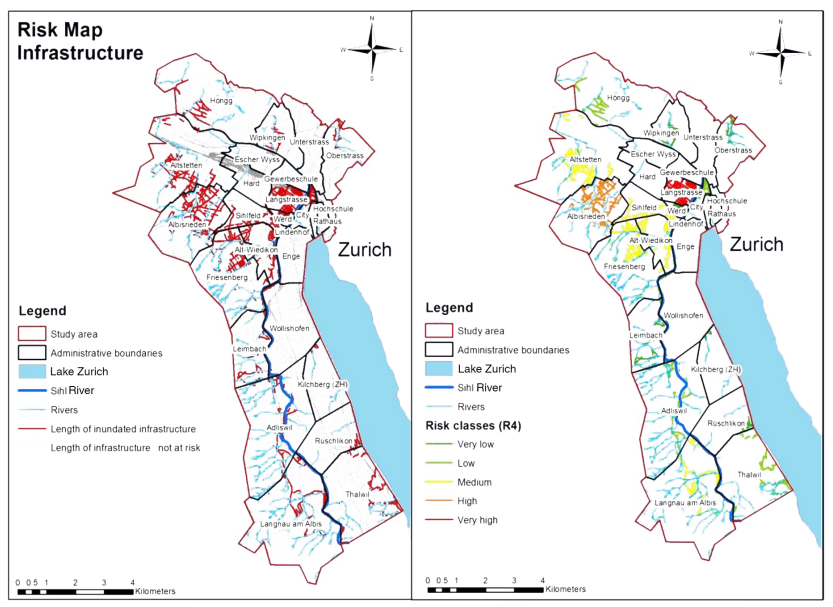

Figure 7. Exposure (left) and relative risk (right) map for infrastructure (roads, railways, pathways).

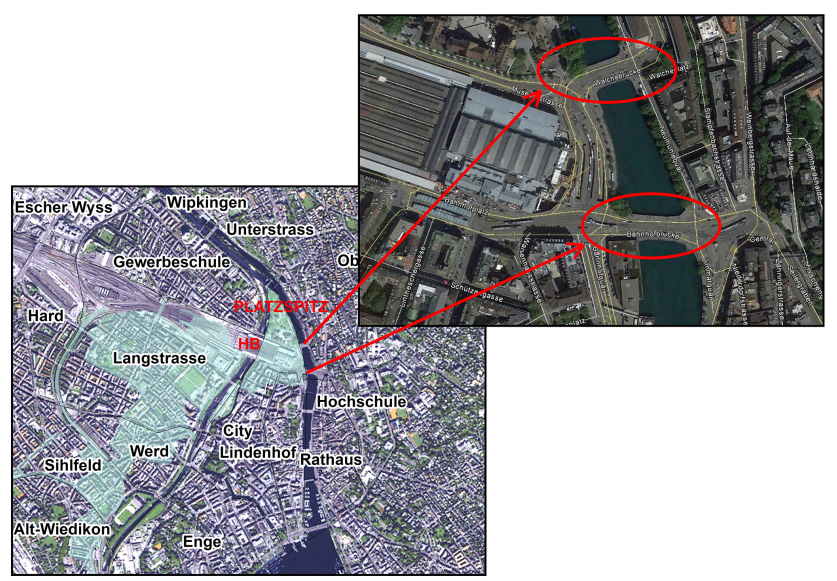

Figure 8. Relevant infrastructure (hotspots) at risk (Langstrasse and City districts and their roads, Zurich central station Hauptbahnhof (HB), Platzspitz, Bahnhofbrücke and Walchebrücke bridges). Source: Google Maps, modified.

risk). In particular, around $54 \mathrm{~km}$ refers to railways network and $155 \mathrm{~km}$ to roads and pathways.

As far as the spatial distribution of the (relative) risk is concerned, the Langstrasse and Albisrieden districts are the
Table 13. Relative risk classes and range of values for infrastructure.

\begin{tabular}{lr}
\hline $\begin{array}{l}\text { Risk } \\
\text { classes (R4) }\end{array}$ & $\begin{array}{r}\text { Infrastructure at } \\
\text { risk within each district }(\mathrm{km})\end{array}$ \\
\hline Very low & $0.01-7$ \\
Low & $7-14$ \\
Medium & $14-21$ \\
High & $21-28$ \\
Very high & $28-32$ \\
\hline
\end{tabular}

most affected by the flood event, belonging to the very high class and high class of risk. The extent of inundated infrastructure for these districts has been computed to be 32 and $26 \mathrm{~km}$, respectively. Moreover, the roads/railway network of Escher Wyss, Unterstrass, Hard and Rathaus districts do not experience any loss of services due to floods.

The infrastructure receptor is very relevant for the city of Zurich if one considers that the Sihl River flows underneath the central station and many railways lines are located just along the river course. An example is Sihltal road (Sihltalstrasse), which runs along the Sihl River for around $16 \mathrm{~km}$, connecting the city district of Zurich with the southern area of the Sihl River valley where the Sihlwald (Sihl natural forest area) ends reaching the Sihlbrugg village. Again, within the district of Langnau am Albis (with almost $17 \mathrm{~km}$ of flooded objects) the railway lines may be completely flooded, as well as most of those of the central station of Zurich in the Langstrasse district. Moreover, several pathways along the Sihl River could be affected. Of course, the flooding of pathways is less relevant than that of highways and railways, especially considering the related economic impact. Therefore, it is particularly important to classify and to rank the different levels of service that the different categories of infrastructure could provide.

Considering the pattern of the urban mobility within the studied area, the following items could be considered the most critical hotspots:

- Part of Zurich central station Hauptbahnhof (HB).

- Zurich city centre with its pedestrian and urban roads in the Langstrasse and City districts, including Bahn- 


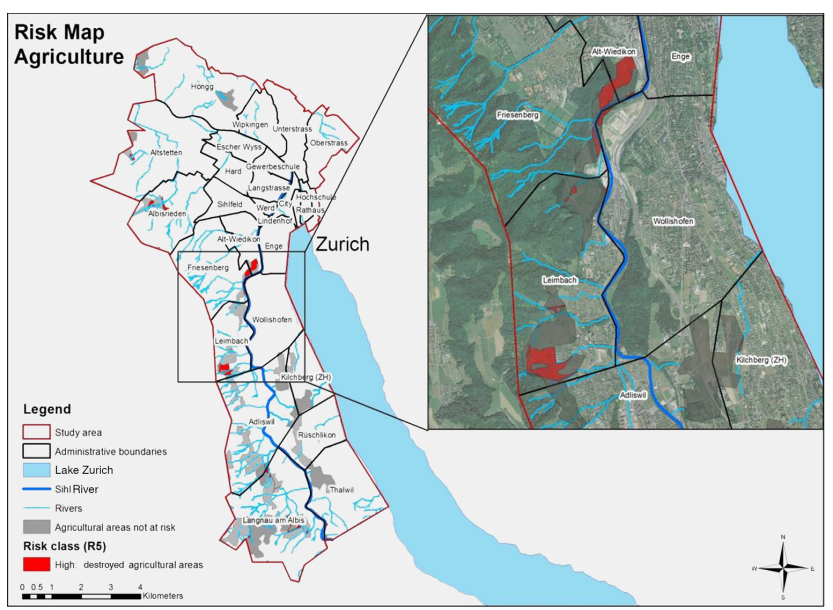

Figure 9. Relative risk map for agriculture, showing flooded and destroyed agricultural areas, with an inset of the most affected area.

hofbrücke and Walchebrücke (two bridges next to the Zurich central station).

- Pathways at Platzspitz green area.

- Railway lines at Langnau-Gattikon train station in Langnau am Albis district.

- Sihltalstrasse in some locations, where the road runs next to the Sihl River, in particular in Adliswil, Leimbach and Langnau am Albis districts.

\subsection{Risk to economic activities: agriculture}

\subsubsection{Assessment}

The flood hazard assessment works on the patterns of water depth and flow velocity, while the exposure assessment allows one to identify the agricultural types present in the Sihl River valley according to the different classes of the CLC data set (class 2.1.1 as non-irrigated arable land and class 2.3.1 as pastures). The total area devoted to agriculture is $7.67 \mathrm{~km}^{2}$, most of it classified as arable land. Since none of the agricultural types mentioned in the companion paper (Part 1) are actually present in the Sihl valley (namely vegetables, vineyards, fruit trees and olive groves), it has been assumed that arable lands and pastures should be classified as vegetables, with similar thresholds.

For the sake of simplification and according to the overall scope of the analysis, it has been assumed that the agricultural crops in the Sihl River valley have similar growing patterns (low-growing plants) and, therefore, the same susceptibility score. According to Torresan et al. (2012) and the technical evaluation of the authors here, the two CLC classes of agricultural types have been considered similar to the class of poor vegetation and meadow (more susceptible to flood) with a score equal to 1 .
Table 14. Relative risk classes and range of values for agriculture.

\begin{tabular}{lrr}
\hline $\begin{array}{l}\text { Risk } \\
\text { classes (R5) }\end{array}$ & Description & $\begin{array}{r}\text { Agricultural } \\
\text { areas }\left(\mathrm{km}^{2}\right)\end{array}$ \\
\hline Not at risk & Not inundated & 7.08 \\
Low & $\begin{array}{r}\text { Inundated } \\
\text { Digh }\end{array}$ & 0 \\
\hline
\end{tabular}

Table 15. Statistics on the risk for agriculture for different CLC classes.

\begin{tabular}{llrr}
\hline $\begin{array}{l}\text { Agricultural } \\
\text { typology } \\
\text { (CLC classes) }\end{array}$ & Description & $\begin{array}{r}\text { Total } \\
\text { area } \\
\left(\mathrm{km}^{2}\right)\end{array}$ & $\begin{array}{r}\text { Flooded } \\
\text { agricultural } \\
\text { area }\left(\mathrm{km}^{2}\right)\end{array}$ \\
\hline CLC class 2.1.1 & $\begin{array}{l}\text { non-irrigated } \\
\text { arable land }\end{array}$ & 7.35 & 0.53 \\
CLC class 2.3.1 & pastures & 0.31 & 0.07 \\
\hline Total & & 7.67 & 0.59 \\
\hline
\end{tabular}

\subsubsection{Results}

The agriculture risk map (Fig. 9 and Fig. 14) has been elaborated according to the procedure introduced above. It is worth noting that despite the fact that the pattern of flow velocity is above the minimum threshold of $0.25 \mathrm{~m} \mathrm{~s}^{-1}$ throughout the area, the risk for the agricultural cluster is very limited: the flooded agricultural area only amounts to $0.59 \mathrm{~km}^{2}$ (around $8 \%$ of the total agricultural area). Out of this, $0.53 \mathrm{~km}^{2}$ belongs to the non-irrigated arable land class (2.1.1) and $0.07 \mathrm{~km}^{2}$ to the pasture class (2.3.1) (Table 15).

The total surface at risk is probably underestimated because the exposure classification, performed according to the CLC resolution, could have missed out some small agricultural areas that might be important for cash crop cultivation.

However, the area of the Sihl River valley is mainly devoted to residential and commercial purposes; therefore, agriculture can be considered less important is compared to the features at risk, such as people, buildings and infrastructure.

\subsection{Risk to natural and semi-natural systems}

\subsubsection{Assessment}

Flood coverage has been used to characterize the hazard affecting the natural and semi-natural systems. As for the other receptors, the CLC classification data set has been used to identify and characterize the natural and semi-natural systems exposed to flooding risk along the Sihl River valley, accounting for more than $20 \mathrm{~km}^{2}$. The valley is characterized by two different kinds of forest systems: coniferous forest $\left(0.21 \mathrm{~km}^{2}\right.$, CLC class 3.1 .2$)$, which covers only a very small area, and mixed forest $\left(19.98 \mathrm{~km}^{2}\right.$, CLC class 3.1.3), which 


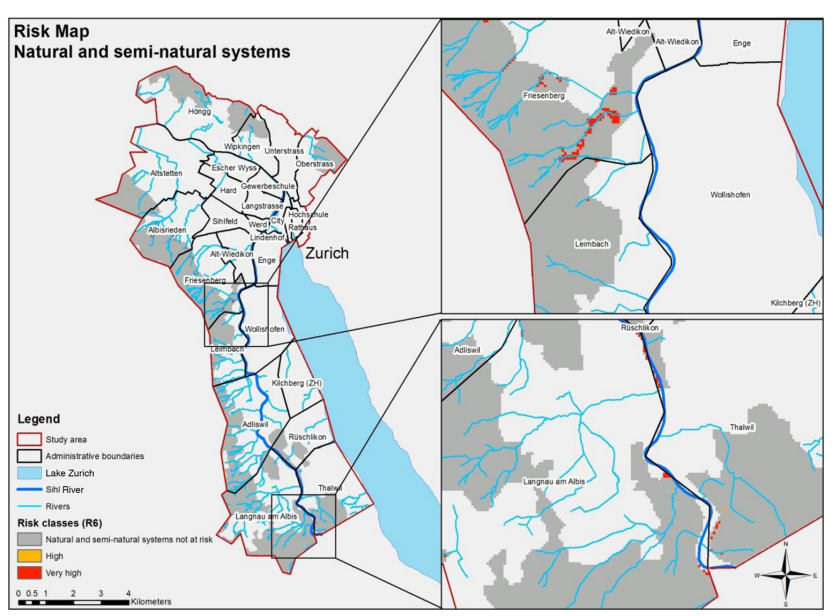

Figure 10. Relative risk map for natural and semi-natural systems (left) with two insets showing details on the most affected area (right).

occupies most of the natural environment in the case study area. The intrinsic characteristics of the territory, namely the (susceptibility) factors that influence the degree of flood impact on the receptors, have been assessed according to the scores suggested in the companion paper (Part 1).

\subsubsection{Results}

The natural and semi-natural systems risk map (Fig. 10) allows one to identify the area potentially affected by loss of ecosystem service caused by a 300-year return period flood event. As a result, only a limited portion of forest is at risk of inundation $\left(0.29 \mathrm{~km}^{2}, 1.4 \%\right.$ of total forest areas) and two classes of risk have been identified: a very small part $\left(625 \mathrm{~m}^{2}\right)$ belongs to the high risk class while the rest (around $289000 \mathrm{~m}^{2}$ ) is characterized by the very high class of risk.

Even if the inundated lands belong mostly to the very high class of risk, due to the different susceptibility factors and in particular to the impermeable ground characteristics of the area and to the (mild) slopes, the risk for this receptor can be considered irrelevant. In fact, forests are generally stable and resilient ecosystems very well adapted to occasional and seasonal flooding because they grow along floodplains. In addition, along the Sihl valley most of the forests are located at higher slopes and this reduces their (physical) susceptibility.

In this sense, the ecological, recreational and economic functionalities of the Sihl valley forest ecosystem is not compromised by flood events of such magnitude.

\subsection{Risk to cultural heritage}

\subsubsection{Assessment}

The hazard assessment step consists of the characterization of the area covered by flooding waters. Moreover, the exposure assessment requires the spatial localization of cultural

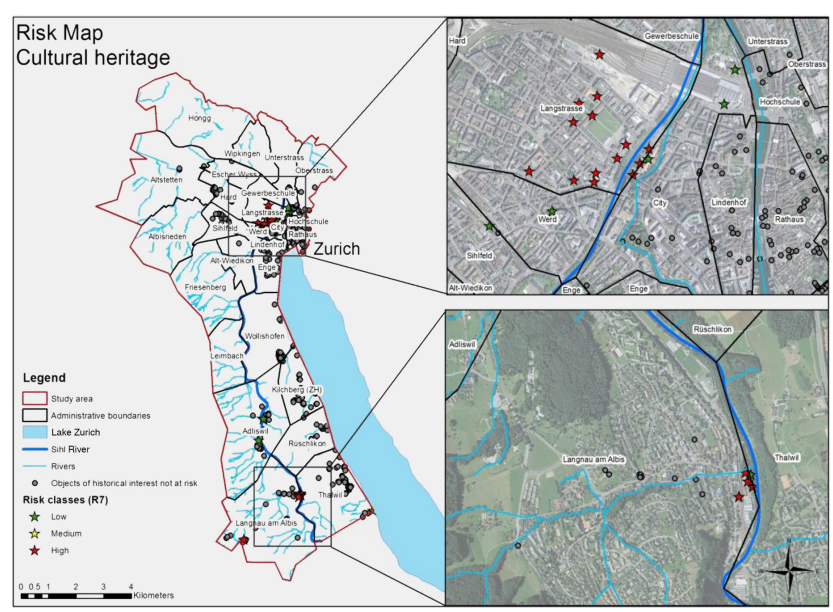

Figure 11. Relative risk map for cultural heritage (left) with two specific areas (right).

heritage assets. Along the Sihl River valley, 416 cultural assets are present, mainly classified as historic buildings. These include different places of worship such as the Fraumünster, Grossmünster and the main synagogue, as well as the Swiss National Museum, the central library of Zurich, the Rathaus (town hall), the Opernhaus, several historic residential buildings and villas in the city centre and along Lake Zurich.

\subsubsection{Results}

The cultural heritage risk map is shown in Fig. 11: it identifies the number of cultural assets which are to be flooded in the framework of the investigated scenario. As a result, 40 objects (out of 416) are expected to be inundated, corresponding to the $9.13 \%$ of the total. These assets belong to different cultural protection levels (regional and cantonal). As already reported, the Swiss National Museum is at risk while the districts belonging to higher class are Langstrasse (close to city centre of Zurich) and Langnau am Albis (along the lower Sihl valley) with 10 to 15 objects affected.

\section{Total risk index}

\subsection{Weighting process}

The total risk index has been calculated aggregating different receptor-related risks by means of multi-criteria decision analysis (MCDA) methods. Prior to this, a normalization process has been performed for each of the analysed receptor in order to rescale the receptor-related risk scores on a numerical scale between 0 and 1 and, therefore, to allow for comparison among (relative) risks expressed in different units of measurement (Zabeo et al., 2011). Within this study, the normalization has been implemented at the CLC polygon level for people, infrastructure and cultural heritage. For buildings, agriculture and natural and semi-natural systems, this proce- 
Table 16. Weight assigned to different receptors by local experts and relevant stakeholders.

\begin{tabular}{lr}
\hline Receptor & Weights \\
\hline Infrastructure & 0.8 \\
Buildings & 0.6 \\
People & 0.4 \\
Agriculture & 0.2 \\
Cultural heritage & 0.1 \\
Natural and semi-natural systems & 0 \\
\hline
\end{tabular}

Table 17. Overall risk index classification and range of values.

\begin{tabular}{lr}
\hline Total risk classes & Score \\
\hline Very low & $0-0.048$ \\
Low & $0.048-0.96$ \\
Medium & $0.096-0.14$ \\
High & $0.14-0.19$ \\
Very high & $0.19-0.24$ \\
\hline
\end{tabular}

dure has been performed according to the relative tables and scores, as follows: flooded buildings -0.2 , lost crops -1 ; natural and semi-natural systems -1 for the very high class of risk and 0.8 for the high class of risk. Normalized risks has been assigned to raster cells of $25 \mathrm{~m}$ resolution that allow a better and more detailed visualization of the spatial variability of the total risk.

The proposed MCDA method of aggregation is the weighted average which considers overlapping receptors' risk to be linearly additive. The ranking process is intended to give numerical priority to those events whose damaging consequences are considered as costly. In this sense, weighting is a typical political decision-making process and the involvement of relevant stakeholders and experts is seen as a fundamental prerequisite for its effectiveness (Yosie and Herbst, 1998). In order to lower the level of arbitrariness derived from expert-based weight selection (Santoro et al., 2013), the weighting process was implemented during a roundtable meeting organized with several local experts involved in the project. They were aware of some preliminary results and this could have influenced their opinion during the assigning of weights. The assigned weights are reported in Table 16 .

The lowest weights have been assigned to relatively less important receptors. Natural and semi-natural systems have scored 0 (zero) because, as stated above, they were considered as stable and very resilient ecosystems without consistent impact from flood events. A weight of 0.1 has been assigned to cultural heritage because these assets have been already included in the buildings analysis, and therefore just an additional, cultural value has been added to the particular building under protection. A weight of 0.2 has been assigned to agriculture because this sector was considered not rele- vant to the socioeconomics of the valley; in fact, there are no valuable cash crops in the flooded agricultural areas.

The people receptor was scored at 0.4 , less than the one assigned to buildings and to infrastructure, and this choice has raised an ongoing discussion. The main argument that has been used to support this assignation is the fact that the selected baseline scenario does not consider the role played by the EWS in mitigating the flood impact on the population living in the studied area. Moreover, it has been argued that the methodology only focuses on the citizens actually living in the residential area, and do not consider the number of people normally present, for example, at the central station and in the main shopping area, which exceeds by far the number of actual residents in that districts, particularly during the daytime and evenings at the weekend. In this sense, local experts and stakeholders argued that the methodology overestimated the risk to people in residential areas and, at the same time, underestimated the risk to other areas. Therefore, a kind of "compensation" in the computation of the total risk index should be considered. Higher weights have been assigned to buildings (0.6) and infrastructure (0.8), which have been considered the most relevant receptors for the socioeconomic context of the Zurich, since damages related to flooded infrastructure and buildings also result in very high (indirect) costs for the loss of their services. In particular, the inundation of the Zurich central station entails a wide loss of services since it represents a very important strategic hub both for public transport connections for the whole canton and for commercial reasons (a big shopping centre area is located in and around the station, frequented by many residents and tourists).

\subsection{Results and discussion}

The total risk map shows the spatial pattern of flood risk and specifically identifies and ranks the hotspots and the areas at risk along the Sihl River valley (Fig. 12). The total surface at risk is $7.98 \mathrm{~km}^{2}$ and the total risk index ranges between 0 and 0.24 (see Table 17), which represents the lower class of risk considering the classification scores presented in Part 1. In order to better visualize the relative distribution of risk belonging to these classes, the green to red spectrum classification, normally representing the $0-1$ range, has been recalibrated according to the calculated range. Langstrasse district and part of the City district of Zurich present the relative highest values of risk; areas within the districts of Werd, Sihlfeld, Alt-Wiedikon and Friesenberg that lie next to the Sihl River course also present relatively higher risk levels. Areas within Albisrieden district are characterized by relative high risk as well. Results are very plausible because they demonstrate that the overall risk is higher close to the central station of Zurich, where lot of infrastructure, railways and buildings would possibly be flooded. Additionally, the left side of the Sihl River before the confluence with the Limmat River is also notably at risk. 


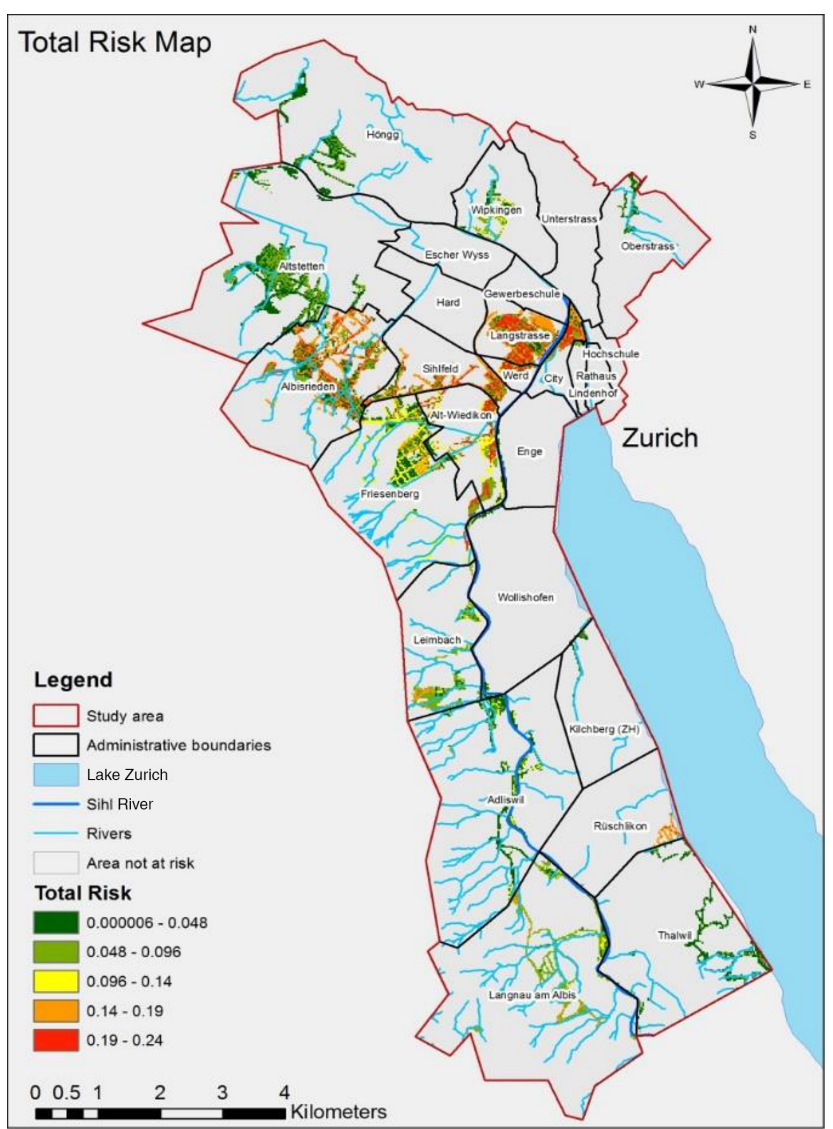

Figure 12. Total risk map for the Sihl River valley considering the 300-year return period scenario.

The total risk index represents a useful indicator which allows for the ranking of "areas more at risk" than others, but it is, of course, highly dependent on receptor-related risk analysis and the weighting process.

When analysing the relative importance and relevance of the different receptors within the local context, it was agreed that infrastructure might be a more major source of risk than human life. In fact, this choice might seem inappropriate, as stated in Sect. 7.1, but it is within the experts' judgement and based on their own experience: the perception of risk during recent events plays a major role. This is what makes KRRRA approach appealing and valuable. Background information from several stakeholders and local experts triggered this choice, starting from forensic analysis (and personal experience) of past events. In fact, since the 1970s Switzerland has experienced several major floods that exceeded a return period of 300 years (e.g. Rössler et al., 2014); however, only three fatalities per year can be attributed to waterrelated disasters (floods, landslides and debris flows) (Hilker et al., 2009). Moreover, Swiss legislation allows settlements only in areas where the buildings are protected by additional measures against floods with return periods between 100 and 300 years. This is not the case for infrastructure, and accord- ing to the latest estimation (pre-KR-RRA), damage of the Zurich central station may trigger costs of over EUR 4 billion. The local authorities are aware of this and are improving their flood management system with additional structural and non-structural measures. The assessment of public perception of these possible future measures has been presented in Buchecker et al. (2013). Thus, a basis for extending the KR-RRA methodology to future flood management in the target area is provided, particularly as far as the roles and responsibilities of local communities (including decision and policy makers) in coping with risk are concerned. In fact, it is an advantage of this novel approach to allow stakeholders and experts to come up with a site-specific suite of weights and thereby improving the adaptation for the local situation. For instance, local authorities reported that after using some standard risk assessment procedure (pre-KR-RRA), a map was created where the most valuable "hotspot" was a tennis resort in the north-western part of Zurich. After including expert knowledge and adapting the weighting accordingly, the areas around central station were chosen as those with the highest risk.

Moreover, it is worth noting that the final risk index aggregates scores come from multiple heterogeneous parameters. The final decision-making process should therefore consider not only the final values of the index, but also the factors that contributed to determining that value (i.e. susceptibility indicators, hazard metrics). A correct interpretation of these factors is particularly relevant for the analysis of the potential prevention measures that could be suitable for reducing the risk in current hotspot areas (Torresan et al., 2012).

It is important to underline that the application of the KULTURisk methodology at the mesoscale provides a screening analysis that allows the assessment and prioritization of targets and areas at risks in the considered region. However, a more detailed analysis (at the microscale) could be required in the areas considered at risk or where more specific information is available.

\section{Conclusions}

The paper deals with the application of a state-of-the-art regional risk assessment (RRA) methodology for flood risk assessment to a very site-specific case, namely the Sihl River valley around Zurich, in northern Switzerland. The complete KR-RRA methodology, developed within the KULTURiskFP7 (KR) Project and introduced in the companion paper (Part 1), followed four subsequent levels of analysis, namely the hazard, exposure, vulnerability and risk assessments. In particular, the paper describes the calibration and implementation procedures that have been applied in order to assess the risk of flood represented by a 300-year return period hazard scenario, this considered the most precautionary one. Relative risk maps (GIS based) and related statistics, specifically on the impact of flood hazard to selected receptors, have 
been developed. By means of MCDA and through a tailored participatory approach with relevant local experts during the weighting process, the total risk maps have been produced allowing the identification of hotspots and areas at risk as well as the spatial characterization of the risk pattern. The total risk maps obtained for the Sihl River case study are associated with the lower classes of risk, while the relative risk is higher in Zurich central districts, and areas that lie just above the Sihl River course.

Including the Zurich case, the KR-RRA methodology has been successfully applied to a wide range of case studies across Europe (not presented in this work), which have contributed to demonstrating its flexibility and possible adaptation to different geographical and socioeconomic contexts, and to complex hazard scenarios, depending on data availability and particulars of the sites. In this sense, the methodology can be easily scaled up in order to evaluate river flood impacts at broader regional, sub-national or national scales (i.e. national level including more than one river basin) or can be detailed over smaller area for impacts at very local scales by using more detailed data sets for the characterization of exposure and vulnerability (i.e. finer digital elevation models and land cover data).

The receptor risk maps, as main outputs of the KR-RRA methodology, have proven to be very useful (and relatively simple) tools for the evaluation of risk in the studied area in order to support the development of knowledge-based decision-making processes and appropriate (risk) management practices (when based on prevention, protection and preparedness concepts). Despite the debatable methodology that has been followed for the assignation of weights, the involvement of relevant local experts have improved the consistency and relevance of the application exercise. Finally, the paper demonstrates the relevance of the KR-RRA methodology, as a comprehensive and integrated assessment tool able for coordinating information coming from deterministic as well as probabilistic flood forecasting and for integrating the multi-faceted physical and environmental aspects of exposure and vulnerability, in order to evaluate flood risks for different elements, as required by the European Floods Directive.

Acknowledgements. This work was funded by the Seventh Framework Programme (FP7) of the European Commission within the collaborative project "Knowledge-based approach to develop a culture of risk prevention (KULTURisk)", FP7-ENV-2010, Project 265280; www.kulturisk.eu. IFKIS Hydro Sihl (Addor et al., 2011) and the work of M. Zappa was financed by the administration of the Canton of Zurich.

Edited by: G. Di Baldassarre

\section{References}

Addor, N., Jaun, S., Fundel, F., and Zappa, M.: An operational hydrological ensemble prediction system for the city of Zurich (Switzerland): skill, case studies and scenarios, Hydrol. Earth Syst. Sci., 15, 2327-2347, doi:10.5194/hess-15-23272011, 2011.

Badoux, A., Andres, N., and Turowski, J. M.: Damage costs due to bedload transport processes in Switzerland, Nat. Hazards Earth Syst. Sci., 14, 279-294, doi:10.5194/nhess-14-279-2014, 2014.

Bezzola, G. and Hegg, C.: Ereignisanalyse Hochwasser 2005, Teil 1-Prozesse, Schaden und erste Einordnung. Bundesamt für Umwelt BAFU, Zurich, Eidgenossische Forschungsanstalt WSL, Umwelt-Wissen, 707, 215, 2007.

Bruen, M., Krahe, P., Zappa, M., Olsson, J., Vehvilainen, B., Kok, K., and Daamen, K.: Visualising flood forecasting uncertainty: some current European EPS platforms - COST731 Working Group 3, Atmos. Sci. Lett., 2, 92-99, 2010.

Bründl, M., Romang, H. E., Bischof, N., and Rheinberger, C. M.: The risk concept and its application in natural hazard risk management in Switzerland, Nat. Hazards Earth Syst. Sci., 9, 801813, doi:10.5194/nhess-9-801-2009, 2009.

Buchecker, M., Salvini, G., Di Baldassarre, G., Semenzin, E., Maidl, E., and Marcomini, A.: The role of risk perception in making flood risk management more effective, Nat. Hazards Earth Syst. Sci., 13, 3013-3030, doi:10.5194/nhess-13-30132013, 2013.

DEFRA Flood Risk to people Phase 2, FD2321/TR2 Guidance Document, Department for environment, food and rural affairs, Wallingford, UK, March 2006.

EEA, European Environment Agency: CLC2006 technical guidelines, Publications Office of the European Union, Luxembourg, 2007.

EEA, European Environment Agency: Report on good practice measures for climate change adaptation in river basin management plans, EEA/ADS/06/001 - Water, Luxembourg: Publications Office of the European Union, 2009.

Giupponi, C., Mojtahed, V., Gain, A. K., Biscaro, C., and Balbi, S.: Integrated Risk Assessment of Water Related Disasters. The SERRA Approach, in: Hydro-Meteorological Hazards and Disasters, edited by: Paron, P. and Di Baldassarre, G., Elsevier, 2014.

Hilker, N., Badoux, A., and Hegg, C.: The Swiss flood and landslide damage database 1972-2007, Nat. Hazards Earth Syst. Sci., 9, 913-925, doi:10.5194/nhess-9-913-2009, 2009.

Hunsaker, C. T., Graham, R. L., Suter II, G. W., O’Neill, R. V., Barnthouse, L. W., and Gardner, R. H.: Assessing ecological risk on a regional scale, Environ. Manage., 14, 325-332, 1990.

IPCC: Intergovernmental Panel on Climate Change: Managing the Risks of Extreme Events and Disasters to Advance Climate Change Adaptation. A Special Report of Working Groups I and II of the Intergovernmental Panel on Climate Change, Cambridge University Press, Cambridge, UK, and New York, NY, USA, 582 pp., 2012.

Jaun, S., Ahrens, B., Walser, A., Ewen, T., and Schär, C.: A probabilistic view on the August 2005 floods in the upper Rhine catchment, Nat. Hazards Earth Syst. Sci., 8, 281-291, doi:10.5194/nhess-8-281-2008, 2008.

Landis, W. G. and Wiegers, J. A. : Design Considerations and a Suggested Approach for Regional and Comparative Ecological Risk Assessment, Human Ecol. Risk Assess., 3, 287-297, 1997. 
Mazzorana, B., Levaggi, L., Keiler, M., and Fuchs, S.: Towards dynamics in flood risk assessment, Nat. Hazards Earth Syst. Sci., 12, 3571-3587, doi:10.5194/nhess-12-3571-2012, 2012.

OPW: Office of Public Work: The Planning System and Flood Risk Management, Guidelines for planning authorities, Environment, Heritage and Local Government, Dublin, Ireland, 2009.

Pasini, S., Torresan, S., Rizzi, J., Zabeo, A., Critto, A., and Marcomini, A.: Climate change impact assessment in Veneto and Friuli Plain groundwater. Part II: A spatially resolved regional risk assessment, Sci. Total Environ., 440, 219-235, 2012.

Pro Sihltal: Lebensraum Sihl, Druckerei Studer AG, Horgen Adliswil, Jahrheft Nr. 58/2008

Rickenmann, D., Turowski, J. M., Fritschi, B., Klaiber, A., and Ludwig, A.: Bedload transport measurements at the Erlenbach stream with geophones and automated basket samplers, Earth Surf. Process. Landf., 37, 1000-1011, 2012.

Romang, H., Zappa, M., Hilker, N., Gerber, M., Dufour, F., Frede, V., Bérod, D., Oplatka, M., and Rhyner, J.: IFKIS-Hydro - Early Warning and Information System for Floods and Debris Flows, Nat. Hazards, 56, 509-527, 2011.

Ronco, P., Gallina, V., Torresan, S., Zabeo, A., Semenzin, E., Critto, A., and Marcomini, A.: The KULTURisk Regional Risk Assessment methodology for water-related natural hazards - Part 1: Physical-environmental assessment, Hydrol. Earth Syst. Sci., 18, 5399-5414, doi:10.5194/hess-18-5399-2014, 2014.

Rössler, O., Froidevaux, P., Börst, U., Rickli, R., Martius, O., and Weingartner, R.: Retrospective analysis of a nonforecasted rainon-snow flood in the Alps - a matter of model limitations or unpredictable nature?, Hydrol. Earth Syst. Sci., 18, 2265-2285, doi:10.5194/hess-18-2265-2014, 2014.

Santoro, F., Tonino, M., Torresan, S., Critto, A., and Marcomini, A.: Involve to improve: A participatory approach for a Decision Support System for coastal climate change impacts assessment. The North Adriatic case, Ocean Coast. Manage., 78, 101-111, 2013.

Scherrer, A. G.: Hochwasser - Hydrologie der Sihl, Hochwasserabschätzung unterhalb des Sihlsees bis Zürich, Zurich, Bericht 12/159, 2013.
Schmocker-Fackel, P. and Naef, F.: More frequent flooding? Changes in flood frequency in Switzerland since 1850, J. Hydrol., 381, 1-8, 2010.

Schwanbeck, J., Viviroli, D., Weingartner, R., Röser, I., and Trosch, J.: Prozessbasierte Abschätzung von Extremhochwassern im Einzugsgebiet der Sihl. Projektschlussbericht, Tech. Report, Geographisches Institut der Universität Bern and TK Consult AG, Zürich, 42 pp., Under commission of the Department of Waste, Water, Energy and Air of Canton of Zürich, 2007.

Schwanbeck, J., Viviroli, D., Weingartner, R., Röser, I., and Trösch, J.: A Statistical Model Derived from Process-Based Modelling to Assist Flood Risk Minimising Reservoir Operation in a PreAlpine Flash Flood Prone Catchment, EGU General Assembly, Vienna, Austria, 2-7 May 2010, EGU2010-4432-1, 2010.

Torresan, S., Critto, A., Rizzi, J., and Marcomini, A.: Assessment of coastal vulnerability to climate change hazards at the regional scale: the case study of the North Adriatic Sea, Nat. Hazards Earth Syst. Sci., 12, 2347-2368, doi:10.5194/nhess-12-23472012, 2012.

Turowski, J. M., Badoux, A., Bunte, K., Rickli, C., Federspiel, N., and Jochner, M.: The mass distribution of coarse particulate matter exported from an Alpine headwater stream, Earth Surf. Dynam., 1, 1-11, 2013.

UNISDR: United Nations Office for Disaster Risk Reduction: Hyogo framework for action 2005-2015: Building the resilience of nations and communities to disasters, secretariat of UN-ISDR, Geneva, 2005.

Yosie, T. F. and Herbst, T. D.: Using Stakeholder Processes in Environmental Decision making. An Evaluation of Lessons Learned, Key Issues, and Future Challenges, Ruder Finn, Washington, 1998.

Zabeo, A., Pizzol, L., Agostini, P., Critto, A., Giove, S., and Marcomini, A.: Regional risk assessment for contaminated sites Part 1: Vulnerability assessment by multicriteria decision analysis, Environ. Int., 37, 1295-1306, 2011.

Zappa, M., Andres, N., Kienzler, P., Naef-Huber, D., Marti, C., and Oplatka, M.: Crash-Tests for forward-looking flood control in the city of Zürich (Switzerland), Proc. IAHS, in press, doi:10.5194/piahs-92-1-2015, 2015. 